\title{
DEGLACIATION OF THE GULF OF FINLAND AND ADJOINING AREAS
}

\author{
ANTO RAUKAS
}

\begin{abstract}
RAUKAS, ANTO, 1986: Deglaciation of the Gulf of Finland and adjoining areas. Bull. Geol. Soc. Finland 58, Part 2, 21-33.

The territory of Estonia was freed from the continental ice in Gothiglacial time during a time span lasting approximately 2000 years. The ice cover began to retreat from the maximum distribution area of the Haanja belt about 13000 years ago, from the Otepää-Karula belt about 12600 years ago, from the Sakala belt about 12250 years ago, and from the Pandivere belt about 12050 years ago. What is now Estonia was finally cleared of ice about 11000 years ago, but before the glaciers temporarily reinvaded the West Estonian Archipelago and northwestern Estonia approximately 11200 years ago. This Palivere belt is well marked with marginal eskers and fluvioglacial deltas and can be traced from the distribution of indicator boulders. Late-glacial sections in northern Estonia exhibit varved clays, massive clays and silts. They contain abundant rebedded pollen, complicating their stratigraphical subdivision and correlation with Finnish sections. All the complexes overlying the till started to accumulate in the Older Dryas or the Alleröd. Big fields of dead ice formed after the readvance of the glacier from the Palivere belt and probably the whole of the Gulf of Finland was occupied by dead ice blocks. Deglaciation in Finland started before the ice blocks melted, and therefore we see no discrepancy between our data and the deglaciation chronology presented in Finland by J. Donner (e.g. 1978).
\end{abstract}

Key words: Gothiglacial, ice marginal formations, dating methods, ice dammed lakes, indicator boulders, biostratigraphy, varve chronology, glacial readvance, correlation, Estonia, Finland.

Anto Raukas: Institute of Geology, Estonian Academy of Sciences, 7, Estonia Avenue, Tallinn, Estonian S.S.R., U.S.S.R., 200101.

\section{Introduction}

The deglaciation of southern Finland and northern Estonia is a classic subject of research. Study of glacial topography and deposits goes back well over a century in Estonia, and an important role has been played in our investigations by the work of G. de Geer, W. Ramsay, F. Schmidt, M. Sauramo and many other worldfamous scientists. Despite the great number of publications and marked improvements in in- vestigation methods many problems of topical interest in the history of deglaciation have still not been solved and require the joint efforts of scientists from many countries. We are, therefore, glad to have the opportunity to collaborate in this field with our Finnish colleagues and we are sure that the outcome will be of great value; after all both countries have a long tradition of research and serious geological study. The extensive distribution of ice marginal formations and deposits of different genesis and structure in 
the territories mentioned undoubtedly play a key role in the solution of a great many problems related to the deglaciation of the Baltic shield and all northern Europe.

\section{Brief description of ice-marginal formations in the northern Baltic area}

As marginal glacial formations we consider the association of relief forms and deposits developed in the marginal area of an active or passive glacier, under the conditions of a more or less stable state of the ice margin. The breadth of the ice margin belts in Estonia fluctuates within a range of tens of metres to some kilometres, and the greatest more or less continuous length being $150 \mathrm{~km}$ (North Pärnumaa marginal esker). Depending on the position of the marginal glacial formations with respect to the margins of an active or passive glacier, they are divided into frontal, intramarginal and extramarginal formations (Gudelis 1963). The size of the formations, which are from some metres to $40-50 \mathrm{~m}$ high (Sinimäed) is determined by the intensity of the ablational and accumulational processes and by the abundance of drift in the glacier. The most typical ice marginal formations in Estonia, as in southern Finland, are marginal eskers and fluvioglacial deltas.

In the course of time, concepts of the glacier's dynamics and ice-marginal zones have been reviewed and elaborated. On the first maps, for example that by H. Hausen (1913), the margin of the glacier was represented more or less schematically as a straight line owing to the scantiness of data. However, J. G. Granö (1922) already mentioned the occurrence of stagnant ice and individual ice lobes and ice islands parallel with the frontal melting of the glacier ice in Estonia. The first researchers to draw attention to the lobated form of the glacier's margin were E. Kraus (1928) and A. Tammekann (1938, 1940). The former attributed the formation of the lobe depressions principally to tectonics whereas the latter attributed it mainly to bedrock relief.
Since the hilly relief is largely in southern Estonia and the elongated ridges are in the northern part of the country, it was long assumed that the glacier lobes in northern Estonia continued to be active practically until they finally melted (Rähni 1963a, 1963b) and that the glacial relief of southern Estonia was formed chiefly as a result of stagnant ice (e.g. Kajak 1963). It is only in the most recent studies (Raukas 1972, Karukäpp, Raukas 1976) that these assumptions have been refuted and that the importance of both stagnant and active ice in the two regions mentioned has been shown.

Although the concept of the extinction of Pleistocene glaciers by way of stagnant ice fields separated from the margin of the active glacier was already familiar before the turn of the century (Chamberlin 1894), researchers still disagreed as to the extent and thickness of these dead-ice fields. E. Antevs (1939) and A. Basalykas (1969) assumed that the ice fields could have been no more than a few kilometres wide, whereas the boundary value of the state of stagnation was the decrease in the thickness of ice to $50-60 \mathrm{~m}$. In contrast, W. Niewiarowski (1963) stated that the zones covered with dead ice could have been as wide as $250 \mathrm{~km}$, and A. Aseyev (1972) and C. Mannerfelt (1945) maintained that the stagnant ice fields separated when the thickness of the ice cover exceeded $500 \mathrm{~m}$ (on the Baltic shield even $700-900 \mathrm{~m}$ ). If that is true, we cannot differentiate the ice marginal zones in our countries. I should mention that, judging by the width of the dead ice field surrounding the IisakuIlluka kame field, the maximum width of the dead ice fields in Estonia is about 15-16 km which is in accordance with data obtained by R. F. Flint (1971), who assumed that the width of the stagnant ice field could have exceeded $10 \mathrm{~km}$. This finding means that we can differentiate active ice marginal formations and correlate them over quite large areas, at least that covered by one glacial lobe. 


\section{Dating methods applied in deglaciation research}

Complex investigations and recent publications in both Finland and Estonia have helped us to agree on the main outlines of deglaciation, but even so many problems remain upon which opinions are still divided, for example, the age of the Palivere and Pandivere marginal zones in Estonia, which, in the light of a superficial estimation, seem to be too young in comparison with the Salpausselkä zones.

One common source of differences in our interpretations is methodological inaccuracy. The morphologically distinct ice marginal formations serve as indicators of the glacial margin but the various ice lobes dependent on the bedrock topography and differences in glacier dynamics are not synchronous and, unfortunately, seldom contain material of use in dating.

For many years, pollen analyses have played a major role in deglaciation studies but they do not provide a direct date for such an event. A big breakthrough in dating methods was the discovery of the ${ }^{14} \mathrm{C}$ method, which has occupied a crucial position in our investigations over the last 20 years. Even so, it has not advanced research as rapidly as was initially expected. Most of our disagreements arise from overestimating the potential of this method. Dates from the crystalline basement, carbonate bedrock and terrigenous bedrock are hardly comparable. For example, depending on the "hard water» effect, above-till sections from the northern Estonian carbonaceous plateau have given ${ }^{14} \mathrm{C}$ dates of more than 14000 years B.P. For example, Upper Dryas deposits from the Loobu section were dated at $13970 \pm 115$ (upper part) and $14725 \pm 260$ (lower part) B.P. In contrast, Prealleröd sediments are without exception terrigenous throughout all the Soviet Baltic republics (Kabailiene, Raukas 1983). Organic matter is embedded in negligible amounts in Bölling sediments. North Baltic Alleröd sediments are also terrigenous. Therefore, we are usually dating rebedded organic material only.

Some of the difficulty of correlating ice marginal formations and the corresponding ice lakes may be due to differential tectonic uplift. It is quite possible that neotectonically active lifting and sinking blocks that were more active in the past, immediately after deglaciation exist in some parts of the sedimentary cover (Fig. 1).

In our joint investigations, we should, therefore, pay much attention to questions of method.

\section{Morphostratigraphy and the evolution of ice-dammed lakes}

In schemes depicting the extension of the glacier, attention has always focused on marking the
Fig. 1. Neotectonically active lifting (I-XV) and sinking (1-5) blocks of the sedimentary cover after E. Rähni and underlying blocks of the crystalline basement after E. Pobul and H. Sildvee with complements of E. Tavast and A. Raukas. 1-2-boundaries of the basement blocks $(1-$ between the largest ones $(\mathrm{A}, \mathrm{B}, \mathrm{C})$ and 2 - between the second stage blocks); 3 - inferred blocks of the sedimentary cover after E. Rähni; 4 - deep faults of the basement; 5 - isopleths of the recent vertical movements after G. Zhelnin.

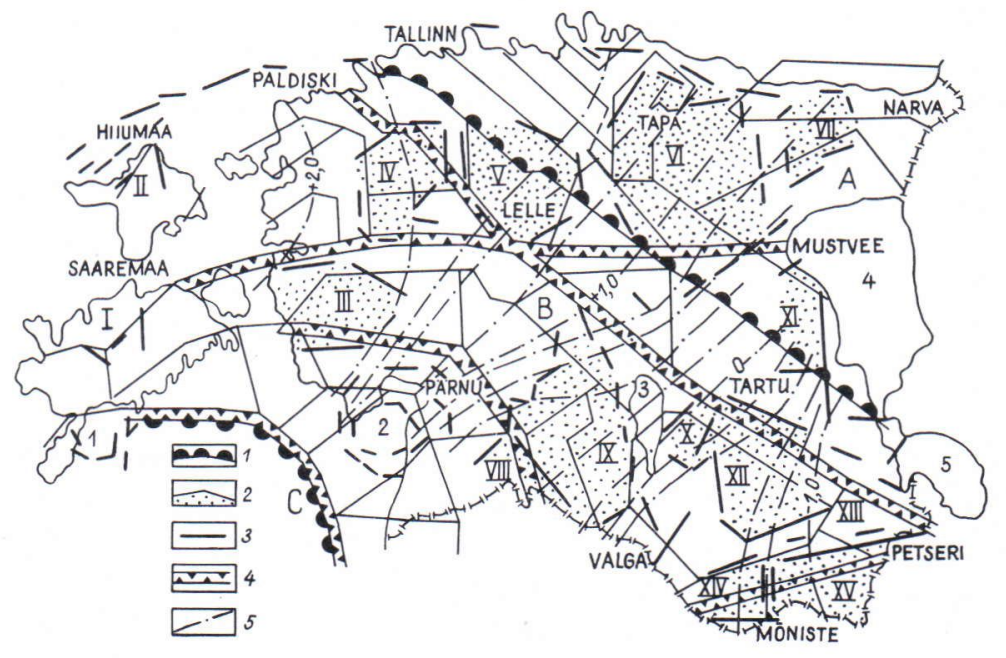


edge of the active ice (Hausen 1913, Ramsay 1929, Raukas, Rähni 1966). This approach is quite justified since the forms shaped by active ice are those that reflect the direction of the movement of ice and the pecularities of its dynamics, and may serve as the basis of correlation schemes. However, this approach is also responsible for a certain overestimation of the effect of active ice upon the shaping of the relief and can lead to errors in our correlation schemes. The role of stagnant ice in the formation of the relief of both Estonia and Finland was undoubtedly, very great indeed. The terrain of both countries was freed from continental ice in Gothiglacial and Finiglacial times, when the glacier ice had become rather thin, and, as a result, conditions were favourable for the formation of extensive stagnant ice fields, both on uplands and within the boundaries of lobe depressions. As a result, most of our correlation schemes are rather speculative in character.

A. Tammekann $(1938,1940)$ and several other scientists considered that ice recession in Estonia

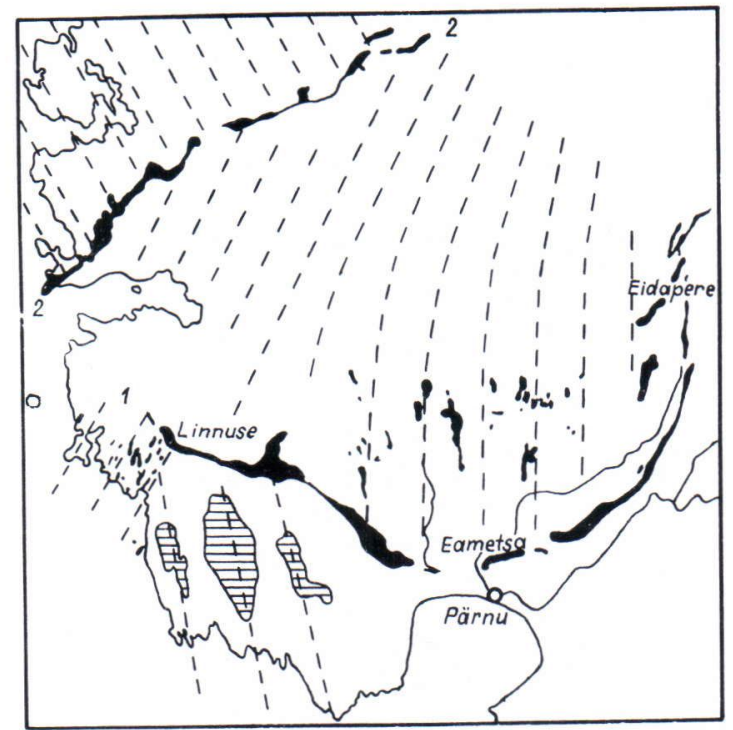

Fig. 2. Marginal glacial formations in western Estonia according to A. Laasi (1937). Dashed lines indicate directions of different age of the movement of the glacier and the lined - surface of drumlins and rock drumlins. Marginal glacial formations: 1 - North Pärnumaa (Pandivere stage); 2 Risti - Palivere (Palivere stage). took the form of a gradual extinction of the margin of the glacier. The majority of contemporary geologists, however, are of the opinion that the recession of the continental ice was a far more complicated process. Moreover, the recession was replaced by repeated advances during stades and phases of sufficiently long duration (Raukas, Rähni 1966). The first to concur with the idea of stadial readvances and advances was E. Piipenberg-Inari (Piipenberg 1935). He found glaciotectonically bruised and crushed varved clays between two till horizons on Lisje peninsula. Taking into account the thickness of the clays and the number of annual varves, he inferred that the interval between the two advances of the glacier was about 1500 years.

Later, the stadial character of ice movements was verified by investigations of the morphology and location of glacial and aqueoglacial relief forms (Fig. 2) by A. Laasi (1937), by lithological data (Raukas 1961) and by abundant intermorainic sections (e.g. Kameri) containing Arctic plant remains (e.g. Betula nana, Dryas octopetala, Salix reticulata) and subfossil molluscs (Orviku 1956, Kajak 1961).

A. Tammekann $(1938,1940)$ identified four stadial ice-marginal belts: Haanja, Otepää and Karula, northern Estonian and northwestern Estonian in Estonia. Smaller zones, well described from the Pandivere Upland by W. Ramsay (1929) occur within their boundaries. Taking all the known facts about the distribution and interior structure of the relief forms and deposits into consideration, the present author (Raukas 1972) identified five stadial belts: Haanja, Otepää, Sakala, Pandivere and Palivere during the last deglaciation in Estonia (Fig. 3). Within their boundaries there are deposits and relief forms that accumulated in the active, stagnant or dead ice. Differentiated stadial belts of glacial marginal formations have no known stratigraphic significance. They can be correlated by morphological data with analogical formations in neighbouring areas. There is a wide variety of correlation schemes, starting with those of G. De Geer and 


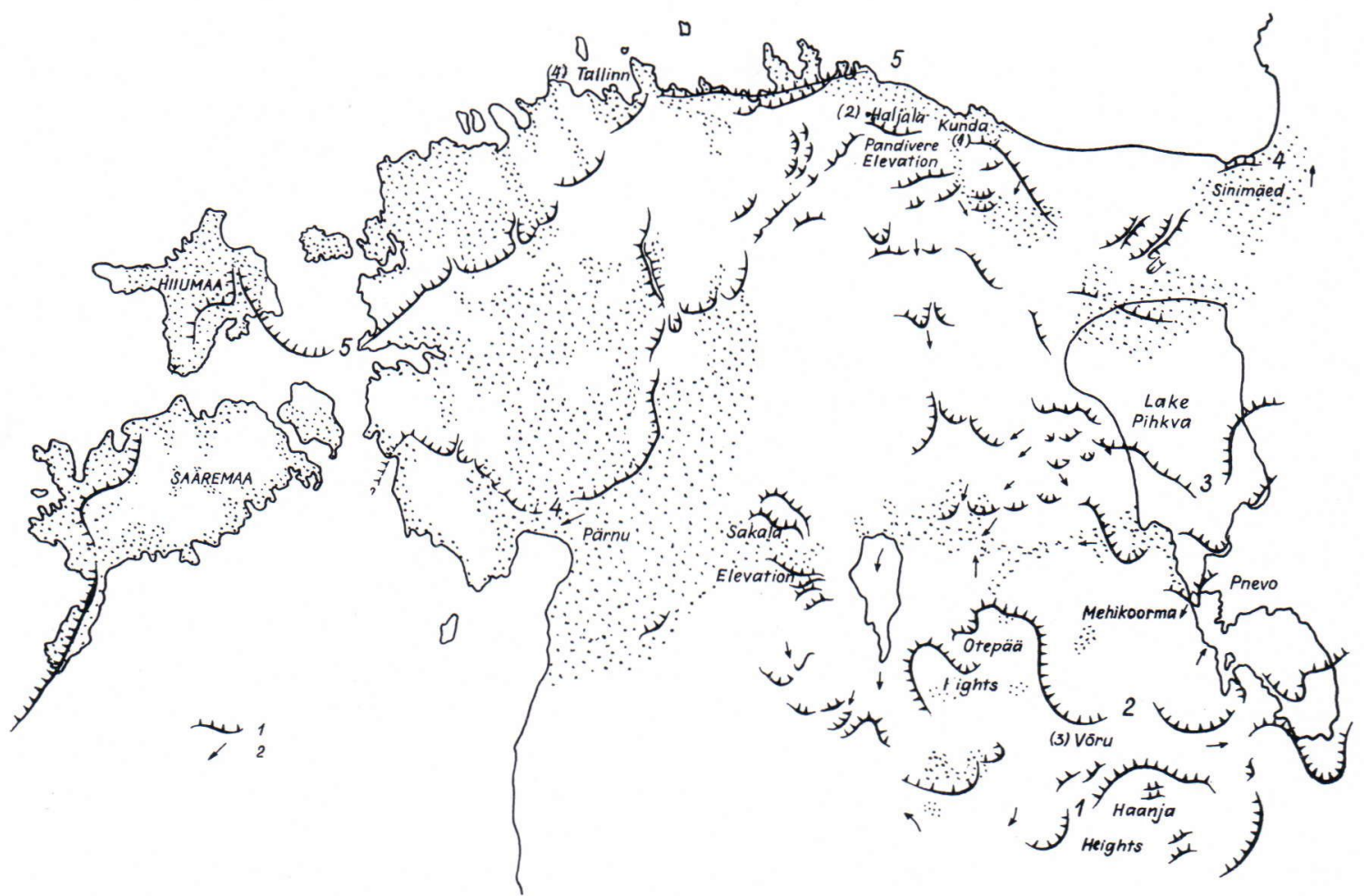

Fig. 3. Main glacial marginal belts (1 - Haanja, 2 - Otepää, 3 - Sakala, 4 - Pandivere, 5 - Palivere) and the distribution of varved clays (dotted areas) in Estonia. Arrows show the drainage direction of the meltwater. Stratotype sections:

1 - Kunda, 2 - Haljala, 3 - Võru, $4-$ Tallinn.

finishing with the most recent schemes of N.-A. Mörner and V. Gudelis but all of them are insufficiently confirmed by factual stratigraphic data.

The history of the formation of ice-marginal belts is genetically connected with the ice-dammed lakes which developed in front of the ice margin. The coastal formations of the ice-dammed lakes are usually small (up to $2 \mathrm{~m}$ high) and unclear in outline owing to the plain relief, the occurrence of abrasion-resistant rocks and deposits in the distribution areas of the lakes, and to the small dimensions, shallowness and brief existence of the lakes on account of which the action of the waves was inconsiderable.

The sediments of small basins on uplands (mainly silts and varved clays) were deposited in the lakes surrounded by ice. They occur at various altitudes (Raukas 1972). For example, corresponding deposits have been found on the Haanja and Otepää Heights at altitudes of over $200 \mathrm{~m}$. Coastal scarps of small ice lakes $G_{o}$ have been recorded on the northern slope of the Sakala Upland and in many other places at altitudes of only $65-73 \mathrm{~m}$.

After the retreat of the continental ice to the north and northwest from the Pandivere Upland, most of the small local ice lakes joined up (Fig. 4) and the big ice-dammed lakes, Voose $G_{1}$ and $\mathrm{Kemba}_{\mathrm{II}}$, formed in front of the glacier margin. The littoral formations of these lakes are represented by fluvioglacial deltas. These deltas are nowadays situated in the northwestern part of the Pandivere Upland, about 83 and $74 \mathrm{~m}$ above sea level, and on the western slope of the Sakala Upland, about 58 and $45 \mathrm{~m}$ above sea 
level (Pärna 1960).

Many redeposited and non-synchronous pollen grains including grains and spores of xerophileus herbaceous plants, Betula nana and other tundra species, have been described from the deposits of the big ice-dammed lakes (Pirrus, Raukas 1969).

The Baltic Ice Lake, which is in a class of its own among ice lakes, is regarded as the first stage in the development of the current Baltic Sea. The map of the highest shorelines in Finland by M. Eronen (1982) shows that the highest shoreline is asynchronous in nature. The isobases on the map do not indicate the situation at any given moment in time for a whole area but simply the height of the boundary between the supra-aquatic and sub-aquatic areas of the region. It becomes younger in a northwesterly direction.

In Estonia the classical coastal formations of the Baltic Ice Lake are represented by five phases $\left(\mathrm{B}_{\mathrm{I}-\mathrm{V}}\right)$, which occurred during the Subarctic climatic period $10800-10200$ years B.P. and correspond, according to palynological data, to the Younger Dryas (Kessel, Raukas 1979). They are distributed throughout the central and northern parts of the country. The clearest level, at an absolute height of $68-32.5 \mathrm{~m}$, was formed during the $\mathrm{B}_{\mathrm{III}}$ transgression approximately $10600-$
10400 years ago. The pollen grains of shrubs and trees account for about $50 \%$ of the silty and clayey deposits of lagoons near Hageri and Kunda, herbaceous plants for about $40 \%$ and spores for about $10 \%$. The bottom deposits of the Baltic Ice Lake are rich in fresh-water diatom flora (about $85 \%$ ). The halophilous $(10 \%)$ and polyhalobous and mesohalobous species may be redeposited here.

In Finland, the interpretations of the relative fluctuations in the water level of the Baltic Ice Lake have been based primarily on the spatial distribution of the marginal deltas or sandur deltas of the Salpausselkä ridges and they do not indicate when this Ice Lake began to develop. In our opinion (Kvasov, Raukas 1970) it started with the retreat of the ice margin from MännikväljaUljaste region in northern Estonia (Fig. 4) about 11900 years ago, as a result of which the icedammed lakes to the west and east joined up to form one large body of water.

The next important stage in Baltic history was the Palivere stage, which in our opinion, occurred about 11200 years ago (Fig. 5), when big fluvioglacial deltas were formed to the west and east of present Tallinn. We assume that there was no inflow of salty ocean water into the Baltic basin in Late Glacial time. During the deglaciation

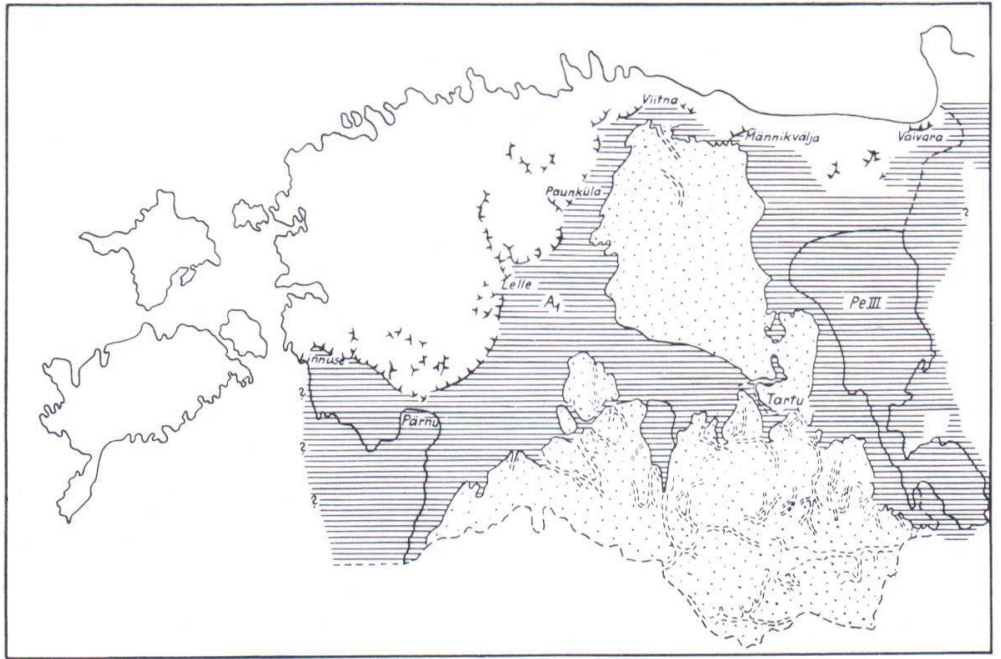

$\square_{1} \varpi_{2} \equiv_{3} \square_{4} \square_{3}$
Fig. 4. Palaeogeographical scheme at the time the glacial margin was along the line Linnuse - Lelle - Paunküla - Viitna - Männikvälja - Vaivara (maximum extent of the glacier of the Pandivere stage after A. Raukas, E. Rähni and A. Miidel). 1 - margin of the glacier; 2 - large crevasses in the glacier and fields of dead ice; 3 territory invaded by glacial lakes; 4 territory free of ice; 5 - valleys. 
period, outflow channels were more likely to have served as the means of removing the fresh water from the Baltic Ice Lake than recurrent intrusion of ocean water into the Baltic Basin.

A significant decrease (c. $25 \mathrm{~m}$ ) in the water level took place about 10180 (10 200) years B.P., owing to the Billingen outflow in central Sweden. This event marks the formation of the Preboreal Yoldia Sea in the Baltic Basin. The drop in the water level is supported by varved clays in Finland, and, according to Sauramo (1923) it caused the formation of the exceptionally thick varve that has been used as the zero varve. The geological history of the Yoldia Sea and younger basins in the depression of the Baltic Sea will not be discussed in the present context.

\section{Lithostratigraphy}

The various tills of different ages from the last glaciation found at many sites in Estonia indicate the stadial-oscillatory character of the deglaciation. It is even possible to correlate stadial and oscillatory sediments with those of neighbouring areas (Raukas 1963a). However, the proportion of clasts and minerals in the tills reflects not only the route of the continental ice but also the dynamics of the glacier's movement. Owing to secondary changes, the rock particles and minerals in tills of different ages differ from each other, but to an inconsiderable extent. Therefore, when drawing stratigraphical and palaeogeographical conclusions, one should take note of the indicator boulders and indicator minerals in the tills as well as the lithological and mineralogical relations of the till particles. The occurrence of the indicator rocks and minerals in tills belonging to different stages of a glaciation is, correspondingly, different.

The distribution of tills and of the indicator boulders occurring in them implies that there were at least four stades during the last (Valdai) continental glaciation in Estonia. Each of the stades is characterized by a certain direction of continental ice flow, differing from that of the other stades and, accordingly, by a certain combination of indicator boulders. The Haanja, Otepää and Sakala stades are characterized by the prevalently southeasterly direction of the continental ice flow, the Pandivere stade by the southerly or even southwesterly direction (west of the Pandivere elevation) and the Palivere stade again by the southeasterly direction with the corresponding composition of indicator boulders (Fig. 5). For example, the tills of the Palivere stade are rich in rapakivis from southwestern
Fig. 5. Rapakivi content in surficial crystalline erratic boulders after $\mathrm{H}$. Viiding (in \%). Rapakivi is found in the localities marked with a plus sign, but the amount has not been determined. The continuous line denotes the westernmost boundary of the Vyborg rapakivi; the dashed line marks the glacial advance of the Palivere stage and the distribution of rapakivi from the Aland islands and from the massifs of southwestern Finland. The big arrows show the main directions of ice movement.

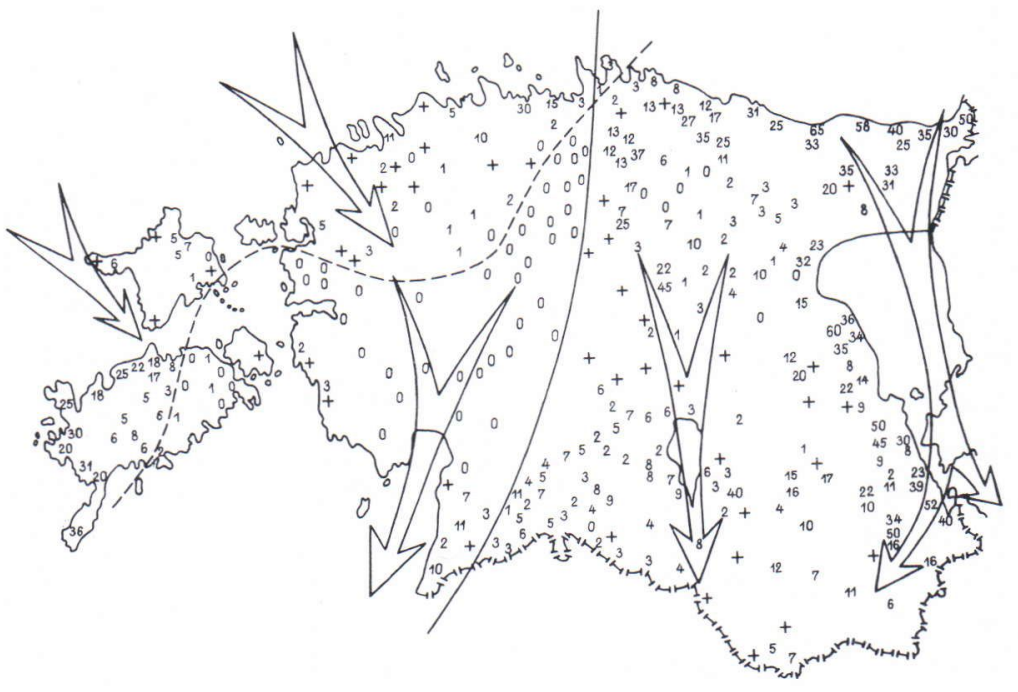


Finland, granites and rapakivis from Åland, Baltic red quartz-porhyries and olivine diabases from Satakunta, all of which are practically absent south of the ice-marginal formations of the Palivere stade.

The centre of the last glaciation appears to have been initially in the Scandinavian Mountains, which explains the prevailing southeasterly direction of the ice movement. As the climate deteriorated, the centre of glaciation was extended over eastern Sweden and central Finland, and the southerly direction of the movement of the continental ice began to dominate. This direction is marked by the maximal distribution of the glacier in Soviet Baltic countries. When the climate improved at the end of the glaciation, the glaciation centre was transferred to the Scandinavian mountains once more, and the direction of ice movement was again from NW to SE. Deviations from that scheme are mostly due to fluctuations in climatic conditions and to the pressure of glaciers coming from other glaciation centres (Raukas 1963b).

The carbonate leaching method cannot be used for dating stadial tills in Estonia as the results obtained depend on the primary carbonate content and matrix of tills, and also on local climatic and geomorphological conditions. This method is also unsuitable for dating subsurface till horizons. It has, however, been used with some success for differentiating between ice marginal formations in Lithuania (Galvidite, Kudaba, Jankauskaite 1970).

\section{Biostratigraphy}

Prealleröd deposits subjected to palynological studies in Estonian territory give evidence of severe climatic conditions throughout the Arctic period, but they do not permit the layers related to the Bölling amelioration to be distinguished (Fig. 6). In Estonia the layers dating from the Older Dryas are represented mainly by limnoglacial varved clays, silts and sands rich in redeposited pollen grains. The amount of redeposited pollen decreases only in the topmost part of these deposits, which contain pollen of shrubs and herbs characteristic of the Older Dryas. The Bölling deposits have been distinguished by palynological data in several Lithuaninan sections (Kabailiene 1965) but even then the deposits of the Arctic period are all rather homogeneous and no distinct indication of their changing composition, which might have served as an indicator of changing physical and geographical conditions, has been revealed so far. Indeed, big pine trunks of Bölling age (11 90012300 years B.P.) are found (Serebryanny, Raukas, Punning 1970) in some parts of southeastern Lithuania (e.g. Rudnja, Pamjarkis, Manciagire), but it is possible that the $\mathrm{C}^{14}$ dates are too old at those sites, and that the deposits really belong to the Alleröd.

Alleröd deposits (about 10 800-11 800 years old) differ by the large amount of organic remains they contain and are considered a stratigraphic reference horizon throughout the Soviet Baltic countries. In Lithuania, Alleröd lake and bog deposits are represented mainly by peat, peaty sapropel, mud and clay with abundant organic matter and remains of higher plants (Kabailiene 1965), but in Estonia, Alleröd deposits are represented by lake silts and clay with only rare dark nests and interlayers of decomposited organic matter (Kajak et al. 1976). In the Alleröd, the whole Baltic area experienced considerable warming. In Estonia, Alleröd deposits are comparatively rich in herb pollen $(10-15 \%)$. The pollen of dwarf birch has also been observed, and even during the climatic optimum its amount reached $6 \%$ in southern Estonian sections and $18 \%$ in those from northern Estonia (Pirrus 1969). This finding shows that conditions were not amenable for the accumulation of organic deposits.

The Upper Dryas deposits (10 000-10 800 years old) are characterized by a very high content of herb pollen $(40-50 \%$ of the total amount of spore and pollen) and dwarf birch. The Younger Dryas cooling gave rise to the development of tundra vegetation once again and deposits from this time are represented by silts and clays. The accumulation of sapropels in Estonian lakes 


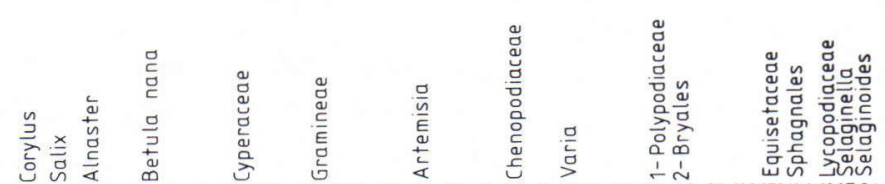



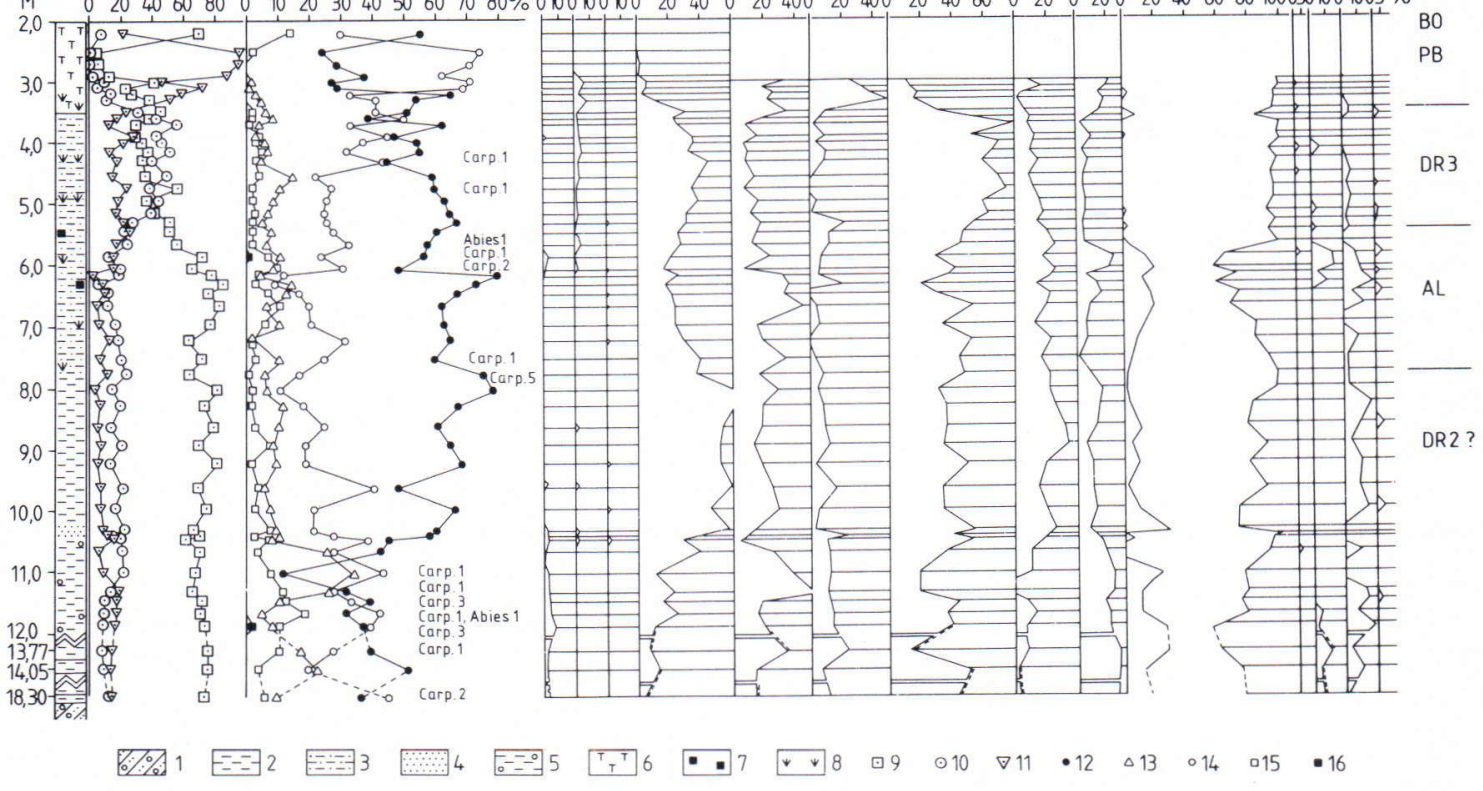

Fig. 6. Pollen diagram of Haljala section in northern Estonia (location, see Fig. 3). 1 - till; 2 - clay; 3 - silty clay; 4 - fine sand; 5 - sandy silt; 6 - lake marl; 7 - organic matter; 8 - plant remains; 9 - tree and shrub pollen; 10 pollen of herbaceous plants; 11 - spores; 12 - pine; 13 - spruce; 14 - birch (pollen of Betula nana is calculated in per cent from all birch pollen); 15 - alder; 16 - broad-leaved trees. Compiled and interpreted by R. Pirrus.

started only in Preboreal time or at the end of the Younger Dryas (at Remmeski about 10200 years ago; Ilves, Liiva, Punning, 1974).

Of greatest interest for correlation with Finland are the northern Estonian late-glacial sections (e.g. Haljala, Loobu, Tallinn, Pudisoo, Kunda). They exhibit varved clays, massive clays and silts and contain appreciable rebedded pollen, making their stratigraphical subdivision extremely complicated (Fig. 6). There is no doubt that Upper Dryas deposits overlie the varved clays and that the whole complex started to accumulate in the Older Dryas or in Alleröd (Kessel, Pirrus 1983).

\section{Chronostratigraphy}

In Estonia, deglaciation has been dated with conventional varve chronology, radiocarbon chronology and TL methods. Only a limited number of methods is available and all are prone to big errors. Non of them can, therefore, be assigned universal validity.

\section{Varve chronology}

The varved clays in Estonia have been little used for geochronological purposes because of their poor outcropping and the high content of natural moisture. M. Sauramo (1925) inferred that Estonian varved clays could not be used in geochronology. In our opinion, however, they can be used for this purpose, particularly in western Estonia, where varved clays are distributed over a wide area. They may thus enable us to estimate with great precision the speed of 
the glacier's retreat, the duration of the stillstands of the ice margin and the existence of ice lakes. The thickness of clays in this part of Estonia reaches $20 \mathrm{~m}$.

In northeastern Estonia the usefulness of varved clays in geochronology has been investigated by E. Rähni (1963a). He assumed (Raukas, Punning, Rähni 1969) that the ice-dammed lakes of Luga-Peipsi and Neva joined up for the first time $12080-12083$ years ago and for the second time 12049 years ago, when a thick (up to $80 \mathrm{~cm}$ ) drainage or overflow varve was formed. Estonian varved clays have recently been investigated palaeomagnetically but the results have not yet been published.

\section{Radiocarbon chronology}

Few of the radiocarbon dates for the deglaciation chronology in Estonia are reliable. The majority of dates of intermorainic or submorainic sequences are younger than one would expect on the basis of the conventional methods. A good example is the sections at Petruse (12 $670 \pm 200$, $12080 \pm 120)$ and Viitka (10 950 \pm 80$)$ in the hilly area of southeastern Estonia, which was freed from ice at least 13000 years ago. In both submorainic sections organic detritus deposited under similar conditions. The remains of a periglacial flora are indicated by single redeposited layers and lenses in sandy-gravel deposits and the dates are not consistent with the bedding of the deposits.

The Rauna Interstade in central Latvia appears to be the best dated interstade of the last glaciation, which started after the retreat of the glacier from the marginal formations of the Luga (Haanja) stade. Datings of this interval made at laboratories in Moscow (13 $390 \pm 500$ ), Tartu (13 $250 \pm 160)$ and Riga (13 $320 \pm 250)$ range between 13500 and 13200 B.P. In the Kurenurme section, southeastern Estonia, remains of Salix wood were taken from sandy loam overlying Luga till. Radiocarbon dating of the wood (12 650 $\pm 520)$ and organic detritus (12 $420 \pm 100$ years B.P.) made at the Tartu laboratory indicates that these deposits accumulated at the beginning of the Bölling interstade. Hence the Luga (Haanja) stade must have taken place at about 13200 to 12700 B.P. and continued for about 500 years, preceeding the Bölling interstade (Serebryanny, Raukas, Punning 1970). Large ice-dammed lakes existed on lowlands both during and after Bölling time. One of them was situated in the Zemgale lowland near Jelgava to the south of Riga. Plant remains from the quarry of the »Progress» brickyard were dated at the Tartu laboratory at 11950 \pm 110 and $11875 \pm 40$ and those from the quarry of the »Sarkanais mals» brickyard at $10390 \pm 105$ years B.P. (Ilves, Liiva, Punning 1974).

The age of the Kunda section between the Pandivere and Palivere ice-marginal belts is currently under the discussion. At this site till is covered by fluvioglacial sands, varved clays, lake sands and marl. P. Thomson (1935) assumed that the varved clays accumulated during Bölling time and the lake marl during Alleröd time. Judging by the materials in adjacent sections, however, this age is too old and, therefore, not reliable. Plant remains below the lake marl have been dated at the Tartu laboratory to $11690 \pm 150$ years B.P. (Ilves, Liiva, Punning 1974). However, this date, too is inconsistent with the latest palynological data, which show them to be from the end of the Younger Dryas.

\section{TL chronology}

Although the nomenclature of the methods applicable to the dating of late-glacial deposits is richer than that for older geological periods, their usage is restricted by the suitability of objects for datings. Hence we cannot use the $\mathrm{C}^{14}$ method more widely in our investigations. At present the thermoluminescent method has claimed particular attention owing to the wide distribution of its study objects, natural quartz and feldspars in deposits. The TL method is much favoured in archaeology for dating the time when individual ceramic objects were made. However, the physical principles of the method are still poorly under- 
stood, since the minerals investigated represent a rather complicated system and microprocesses occurring in it can be modelled only at the empirical level (Dreimanis, Hütt, Raukas, Whippey 1978). Another serious problem in dating geological objects is how to establish the zero point for the time of the formation of the minerals studied. We have about ten TL dates for upper Valdaian till and adjoining aqueoglacial deposits but they are all substantially older than would be expected on the basis of traditional deglaciation chronology.

\section{Glacial readvance from Estonia and correlation of deglaciation chronology between Estonia and Finland}

The stages of deglaciation differed depending upon the form and thickness of the glacier, subglacial topography, tectonic movements and climatic changes (Raukas, Karukäpp 1982). In Daniglacial time the peripheral part of the glacier was supplied from the central shield and in the southern Baltic it formed extensive marginal heights and end moraines accompanied by stagnant ice and periglacial forms.

In Gothiglacial time, when Estonia became free of ice, the central shield of the glacier diminished considerably, the supplement of the peripheral cover decreased and the movement of ice streams and lobes differentiated. Ice sheds of convergent type formed between the streams of the peripheral ice cover and accumulative insular heights developed. The differentiated dynamics of the glacier resulted in the formation of a rather diverse relief complex comprising all the genetic types of exarative, exarative-accumulative and accumulative relief forms.

In the last, Finiglacial, stage, when Finland became free of ice, the ice retreated more rapidly. The ice margin withdrew as a compact and almost straight front line with subsequent parallel marginal belts. This stage is characterized by marginal eskers, extensive deltas and numerous stagnant ice forms.
Since deglaciation depends to a considerable extent upon the pecularities of the above-mentioned glacier dynamics, mechanical correlation of the deglaciation chronology in Estonia and Finland is impossible. What is more, we do not know the nature of the deglaciation of the Finnish Gulf. Its central parts at least were probably occupied by huge blocks of dead ice and therefore deglaciation in Finland started before the ice blocks melted.

Taking into account the above-mentioned data on varved clays in northeastern Estonia, radiocarbon datings of the Rauna section, the possible speed of the ice retreat (about $150 \mathrm{~m} /$ year), new stadial advances, geomorphology, palynology and lithology and analogical works in Latvia, Lithuania and the Leningrad district, we suggest that the territory of Estonia was freed from the continental ice sheet in Gothiglacial time during approximately 2000 years. At the beginning some 13000 years ago, the extreme southeastern part of the country and the central part of the Haanja heights emerged from under the ice sheet (Fig. 3). Approximately 12600 years ago the marginal formations of the continental ice sheet were formed in the region of the Otepää heights and Karula (Fig. 3), and about 12250 years ago the Sakala belt. About 12050 years ago the ice began to retreat from the belt of marginal formations of the Pandivere stage (Fig. 4). The final liberation of the land from the ice sheet probably occurred during the Alleröd stage, because, according to pollen evidence, the immediate effect of the glacier in northern Estonia did not cease until the beginning of the Alleröd (Pirrus, Raukas 1969). If our varve data and K. Markov's investigations in the Leningrad district are correct, the glaciers readvanced temporarily approximately 11200 years ago (Palivere stade), leading to the formation of central heights of Saaremaa, the Risti-Palivere marginal eskers and the fluvioglacial delta deposits between Tallinn and Kunda (Raukas, Punning, Rähni 1969; Raukas, Rähni, Miidel 1971).

We do not see a meaningful discrepancy be- 
tween our data and the deglaciation chronology established in Finland by J. Donner (e.g. 1978), taking into account the possible covering of the Gulf of Finland with dead ice. Some disagreements as to the age of the Palivere and Pandivere zones can surely be solved by joint investigations. We cannot agree with the mechanical revisions of deglaciation schemes, as done, for example, by B. E. Berglund (1979). In our opinion, the changes in the glacier dynamics are not directly correlated with climatic changes, and in some places deglaciation could have been more or less rapid, even at the margin of the same ice lobe, not to speak of various lobes in climatically, tectonically and morphologically highly diverse regions as, for example, Norway and eastern Sweden. Asynchronity of geological events is

\section{References}

Antevs, E., 1939. Models of retreat of the Pleistocene ice sheets. Journ. Geol. 47: 5, 503-508.

Aseyev, A. A., 1972. Forms of degradation of continental glaciation and types of ice-marginal formations. In: Kraevye obrazovanija materikovǒh oledenenii. Moscow, 50-64 (in Russian).

Basalykas, A. B., 1969. Diversity of the relief in glacialaccumulative region. In: Materikovoe oledenenije i lednikovyi morphogenesis. Vilnius, 65-154 (in Russian).

Berglund, B. E., 1979. The deglaciation of southern Sweden 13 500-10 000 B.P. Boreas, 8: 2, 89-117.

Chamberlin, T. C., 1894. Proposed genetic classification of Pleistocene glacial formation. Journ. Geol. 2: 2, 517-538.

Donner, J., 1978. The dating of the levels of the Baltic Ice Lake and the Salpausselkä moraines in south Finland. Comm. Phys.-Math. 48: 1, 11-38.

Dreimanis, A.; Hütt, G.; Raukas, A. \& Whippey, P. W., 1978. Dating methods of Pleistocene Deposits and their Problems: I Thermoluminescence Dating. Geoscience Canada 5: 2, 55-60.

Eronen, M., 1982. The course of shore displacement in Finland. In: Holocene sea level fluctuations, magnitude and causes. University of South Carolina, Columbia, 43-60.

Flint, R. F., 1971. Glacial and Quaternary geology. New York - London - Sidney - Toronto, 880 pp.

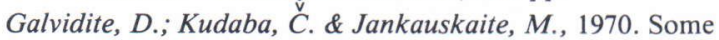
criterion to distinguish phasial ice-marginal belts on the western slope of Baltic Heights. In: Nautshnye trudyi vyshih utshebnyh zavedenii Litovskoi SSR, Geographija i Geologija, 7, 213-219 (in Russian). well documented even in the Holocene. Therefore the compilation of detailed ice-border maps for the areas surrounding the Baltic is of little scientific interest, all such maps being more or less hypothetical.

Acknowledgements. I am deeply indebted to Professor Joakim Donner for supporting and critical revising of the manuscript, and to Mrs. Gillian Häkli for improving my English language. My warmest thanks are due to the Geological Society of Finland for printing of my paper and to Dr. Seppo Lahti for editing the manuscript. I am indebted to the Finnish Academy and the Academy of Sciences of the U.S.S.R. for providing the possibility to perform joint studies within the frames of the project »The geology of the Baltic Sea and the effect of continental glaciers on the formation of the Quaternary layers» which undoubtedly will reveal several new aspects and data as regards the deglaciation of the Gulf of Finland and adjoining areas.

Granö, J. G., 1922. Estonian landscape units. Loodus 2, $105-123 ; 4,193-214 ; 5,257-281$ (in Estonian).

Gudelis, V. K., 1963. On the terminology and classification of ice-marginal formations. In: Trudyi Komissii po izucheniju tshetvertitshnogo perioda 21, Moscow, 84-91 (in Russian).

Hausen, H., 1913. Über die Entwicklung der Oberflächenformen in den russischen Ostseeländern und angrenzenden Gouvernements in der Quartärzeit. Fennia, 34: 3, 142 pp.

Ilves, E.; Liiva, A. \& Punning, J.-M., 1974. Radiocarbon dating in the Quaternary geology and archaeology of Estonia. Tallinn, 231 pp. (in Russian).

Kabailiene, M. V., 1965. Some stratigraphical and palaeogeographical problems of the Holocene in South-East Lithuania In: Stratigraphija tsetvertitshnyh otlozhenij i paleogeographij antropogena Yugovostotshnoi Litvyi. Vilnius, 302-336 (in Russian).

— \& Raukas, A., 1983. Stratigraphy of lake-bog deposits and climatic changes in late-glacial and Holocene on the territory of the Baltic Soviet Republics. Abstracts of papers. Symposium in U.K. 19-26 Sept. Southampton, $33-35$.

Kajak, K., 1961. Stratotype section of Quaternary deposits on Prangli island. VI Eesti loodusuurijate päeva ettekannete teesid. Tartu, 20-21 (in Estonian).

-, 1963. On the ice-marginal formations in South-East Estonia. In: Trudyi Komissij po izucheniju tshetvertitshnogo perioda, 21 Moscow, 66-75 (in Russian).

-; Kessel, H.; Liivrand, E.; Pirrus, R.; Raukas, A. \& Sarv, $A ., 1976$. Local working stratigraphical scheme of Estonian Quaternary deposits. In: Stratigraphija tshetvertitshnyh otlozhenij Pribaltiki. Vilnius, 4-52 (in Russian). 
Karukäpp, $R . \&$ Raukas, A., 1976. Stagnant ice features in the Estonian glacial relief. In: Estonia. Regional studies. Tallinn, 34-44.

Kessel, H. \& Raukas, A., 1979. The Quaternary history of the Baltic. Estonia. In: The Quaternary History of the Baltic. Acta Univ. Ups. Symp. Univ. Ups. Annum Quingentesimum Celebrantis. Uppsala, 127-146.

— \& Pirrus, R., 1983. Problems of the stratigraphical subdivision of late glacial deposits in the Estonian territory by palynological data. In: Palinologijy v geologitseskih issledovanijah Pribaltiki i Baltiskogo morja. Riga, 14-17 (in Russian).

Kraus, E., 1928. Tertiär und Quartär des Ostbaltikums. In: Ostbaltikum 2, Berlin, 142 pp.

Kvassov, D. D. \& Raukas, A. V., 1970. On the late-glacial history of the Finnish Gulf. Izvestija Vsesojuznogo geographitcheskogo obshstsestshva 5, 432-438 (in Russian).

Laasi, A., 1937. About the Pǒhja-Pärnumaa end moraine. Eesti Loodus 2, 67-71 (in Estonian).

Mannerfelt, C. M., 1945. Nagra glacialmorfologiska formelement. Geogr. Annaler 27, 1-239.

Miewiarowski, W., 1963. Some problems concerning deglaciation by stagnation and wastage of large portions of the ice-sheet within the area of the last glaciation in Poland. In: Rep. 6th Conf. Int. Ass. Quatern. Res. (Warsaw, 1961), Vol 3. Lodz, 245-256.

Orviku, K., 1956. Stratigraphical scheme of Anthropogene (Quaternary) deposits of Estonian SSR. ENSV Teaduste Akadeemia Geoloogia Instituudi Uurimused, I. Tallinn, 105-112 (in Russian).

Piipenberg, E., 1935. Notes of the varved clays in Setumaa. Eesti Loodus 3, 102 (in Estonian).

Pirrus, R., 1969. Stratigraphical subdivision of late-glacial deposits in South Estonia by palynological data. In: Eesti NSV Teaduste Akadeemia Toimetised. Keemia-Geoloogia, 18: 2, 182-191 (in Russian).

- \& Raukas, A. On the character and time of deglaciation of the Estonian territory from the glaciers of the last glaciation. In: Trudyi po tshetvertitshnoi geologii, 4, Riga, 47-57 (in Russian).

Pärna, K. T., 1960. On the geology of the Baltic Ice Lake and big local ice-dammed lakes on the territory of Estonia. In: Eesti NSV Teaduste Akadeemia Geoloogia Instituudi Uurimused, V, Tallinn, 268-278 (in Russian).

Ramsay, W., 1929. Nieveauverschiebungen, eisgestaute Seen und Rezession des Inland-eises in Estland. Fennia 52: 2, 48 pp.

Raukas, A., 1961. Application of the mineralogical method to the investigation of tills in Estonia. In: Eesti NSV Teaduste Akadeemia Geoloogia Instituudi Uurimused, VII. Tallinn, 55-67 (in Estonian).

-, 1963a. The lithology of Estonian tills of a different age. Eesti NSV Teaduste Akadeemia Geoloogia Instituudi
Uurimused XII. Tallinn, 3-21 (in Russian).

,$- 1963 \mathrm{~b}$. Distribution of indicator boulders in the till of the last continental glaciation in the Estonian S.S.R. Eesti NSV Teaduste Akadeemia Toimetised. Füüsika-, matemaatika- ja tehnikateaduste seeria XII, 2, 198-211 (in Russian).

-, 1972. The formation of the Estonian glacial relief. In: Estonia. Geographical studies. Tallinn, 7-14.

— \& Karukäpp, R., 1982. Differences in glacial dynamics and glacial lithomorphogenesis at different stages of the recession of the last glaciation. In: Data of geological studies. Chronicles, discussion, 34, Moscow, 117-121 (in Russian).

_; Punning, J.-M. \& Rähni, E., 1969. When did the continental ice-sheet retreated from Estonia? Eesti Loodus, 7, 396-401 (in Estonian).

- \& Rähni, E., 1966. On the regression of the last continental ice from the territory of the Estonian S.S.R. In: Eesti Geograafia Seltsi aastaraamat 1964/1965. Tallinn, 5-17 (in Russian).

—; Rähni, E. \& Miidel, A., 1971. Marginal glacial formations in North Estonia. Tallinn, 226 pp (in Russian).

Rähni, E., 1963a. Ice-marginal formations of the last glaciation in North-Estonia In: Trudyi Komissii po izucheniju tshetvertitshnogo perioda, 21. Moscow, 60-65 (in Russian).

-, 1963b. On the geochronology of Northeast-Estonian varved clays. Eesti NSV Teaduste Akadeemia Geoloogia Instituudi Uurimused, XII. Tallinn, 81-94 (in Russian).

Sauramo, M., 1923. Studies on the Quaternary varve sediments in southern Finland. Bull. Comm. geol. Finlande 60; Fennia 44 (1), 164 pp.

-, 1925. Über die Bändertone in den ostbaltischen Ländern vom geochronologischen Standpunkt. Fennia 45, 6, 9 p. +3 fig.

Serebryanny, L.; Raukas, A. \& Punning, J.-M., 1970. Fragments of the natural history of the Russian plain during the Late Pleistocene with special reference to radiocarbon datings of fossil organic matter from the Baltic region. Baltica 4, 351-366.

Tammekann, A., 1938. Die Endmoränen in Estland. In: C. R. du Congrès International de Geographie Amsterdam. Union Geographique Internationale. Leiden, 251256.

,- 1940 . The last recession of continental ice and end moraines. In: IV Eesti loodusteadlaste päev 18. ja 19. märtsil 1940. Ettekannete kokkuvǒtted. Tartu, 30-33 (in Estonian).

Thomson, $P$. W., 1935. Vorläufige Mitteilungen über die spätglaziale Waldesgeschichte Estlands. Geol. Fören. i Stockh. Förhandl. 57: 1, 84-92.

Manuscript received 25. November, 1984 